\title{
Centre des Sciences humaines, Côte d'Ivoire
}

Au cours de l'année 9 $_{963}$ et au début de 1964 , les activités du Centre des Sciences humaines en Côte d'Ivoire se poursuivent de façon régulière, malgré quelques difficultés d'ordre matériel. Faute de moyens et de personnel technique indispensable notamment pour la conservation matérielle des très nombreuses collections du Musée d'Abidjan, certaines réalisations du programme prévu ont dû être reportées à plus tard. Néanmoins, les enquêtes commencées depuis de longues années se poursuivent, et certains sujets ont déjà été rédigés sous une forme définitive, et sont prêts à publication.

Une étude consacrée au problème du séparatisme religieux en Afrique noire et en particulier en Côte d'Ivoire, se trouve justement sous presse sous la signature de B. Holas. D'autres suivront au cours de cette année ou de l'année suivante. Un album illustré d'arts ivoiriens est également en préparation.

Les enquêtes régionales ont permis de constituer de dossiers importants qui se trouvent actuellement à l'état de dépouillement: il s'agit des groupes ethniques bété, gagou et sénoufo.

\section{The Unesco East-West Major Project}

IN 1956 the General Conference decided in favour of the implementation, for a ten-year period, of a Major Project on Mutual Appreciation of Eastern and Western Cultural Values. An account of the fifth session of the Advisory Council for the Major Project, held in Paris from 9 to $1_{3}$ September $196_{3}$, is given in the Unesco Chronicle (vol. ix, November $19^{6} 3$ ). As far as Africa was concerned, it was stated that "it has hardly been possible as yet to achieve the objectives of the Major Project. To avoid harmful maladjustment in the appreciation of African values and of their relationship to those of other civilizations, however, "due allowance must be made for difference in the level of cultural facilities". The committee recognized that the "fundamental problems in connexion with the execution of the Major Project were the re-evaluation of the African cultures and the appreciation of their infinite diversity ". In response to the wish expressed by Africans, it asked the Organization to pay special attention to those problems in connexion with its programme for the study, preservation and presentation of African cultures '.

\section{The First Conference of African National Commissions for Unesco}

The First Regional Conference of African National Commissions for Unesco was held in Kampala, Uganda, from 9 to 14 September 1963 . It was attended by the representatives of National Commissions in twenty-three countries while five other African States sent observers. Four Commissions were established to study the main items on the agenda: the role and resources of National Commissions, the implementation of the Addis Ababa plan for educational development and the recommendations of the Tananarive Conference on the Development of Higher Education in Africa, Unesco's programmes for the application of science and technology for the benefit of the less developed areas, and the preservation and development of African cultures. Alluding to the cultural problems of these countries, the Director-General mentioned the assistance being provided by the Organization for Institutes of African Studies and the part it had played in the establishment of the International Congress of Africanists. "Without intervening directly in the elaboration of the very substance of culture-for that is not its function-Unesco is promoting all forms of action which will enable that culture to find expression and to develop: museums and libraries, exhibitions and publications, conferences and round tables.'

Proceeding from the principle that 'the peoples of Africa cannot worthily occupy their 
just place in the world unless they preserve their cultural heritage which is the most distinctive feature of their individuality', the delegates urged the adoption by the General Conference, at its next session, of 'an emergency programme designed to hasten the process of preservation and development of African cultures'. They considered 'that a national cultural policy in Africa necessitates the conduct, at the same time, of general literacy campaigns making use of powerful means to place the essential results of African research at the disposal of the masses' and recommended that all African States 'give a considerable place in their school and college educational curricula to African culture'.

\section{International Congress of African History}

THE Society of African Culture (Présence Africaine) is organizing an International Congress of African History to take place in Dar-es-Salaam, Tanganyika, from I to 7 September I964. The main themes of the Congress are to be the principles and methods of African historiography, African history and associated sciences, and the organization and practical problems of research work in African history. Myths, sources, chronological divisions and territorial structures, and the diffusion of African history in schools will be among the aspects treated under the first heading, while African history will be related to geography, archaeology, linguistics, anthropology, and sociology under the second. Organization and practical problems will include a critical inventory of present-day publications, local archives and study centres, discussion of practical methods for recording oral traditions, inter-African and international co-operation, and a project for a basic school textbook. Further information about the Congress may be obtained from the Society of African Culture (Présence Africaine), 42 rue Descartes, Paris $5^{\mathrm{e}}$.

\section{African Museums}

Museum, the quarterly review published by Unesco, has devoted a recent number (vol. xvi, no. 3, 1963 ) to African museums. The following articles are included:

The Museums of Nigeria

The Uganda Museum, Kampala: the programme and the organization

The Uganda Museum, Kampala: the public

The National Museum of Tanganyika, Dar-es-Salaam

The Rhodes-Livingstone Museum, Livingstone

The National Gallery of Salisbury and its workshop-school

The Coryndon Museum, Nairobi, and the role of natural history museums in Tropical Africa

The National Museum of the Republic of Niger, Niamey

\section{Bernard Fagg}

Merrick Posnansky

Valerie Vowles

Stanley E. West

Gervase C. R. Clay

Frank McEwen

R. H. Carcasson

Pablo Toucet

Museum may be obtained from H.M. Stationery Office, P.O. Box. 569, London, S.E. I.

\section{Unesco Directory of Specialists in African Studies}

A DrRECTORY entitled Social Scientists Specializing in African Studies has been prepared by the Secretariat of Unesco. Its principal aim has been to achieve as large a coverage as possible and it brings together data on social scientists specializing in African studies from the whole African continent as well as from countries all over the world. Priority has been given to specialists in the central disciplines in the social sciences, such as economics, social and cultural anthropology, sociology, psychology, political science, and law, and also to more specialized fields such as rural and industrial sociology, labour relations, \&c. A certain number of specialists in archaeology, history, folklore, musicology, and linguistics have 